\title{
Irmandade Muçulmana: da fundação à derrubada de Mubarak
}

José Antonio Geraldes Graziani Vieira de Lima

Resumo: Este artigo reconstrói a história da Irmandade Muçulmana, principal movimento do islã político, ao longo da história do Egito, perpassando o período monárquico e as ditaduras de Nasser, Sadat e Mubarak. O objetivo é provocar a discussão a respeito da organização e contribuir para as análises acerca do Egito e do Oriente Médio.

Palavras-chave: Egito. Irmandade Muçulmana. Islã Político. Oriente Médio.

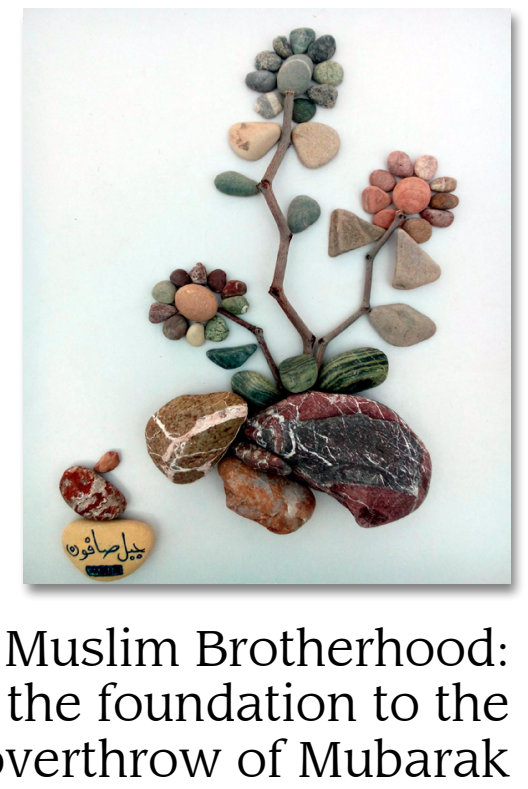

Abstract: This article reconstructs the history of the Muslim Brotherhood, the main movement of political Islam, throughout the history of Egypt, spanning the monarchist period and the dictatorships of Nasser, Sadat and Mubarak. The objective is to provoke the discussion concerning the organization and to contribute to studies on Egypt and the Middle East.

José Antonio Geraldes Graziani VIEIRA DE LIMA

Doutorando e mestre em Relações Internacionais pelo Instituto de Relações Internacionais da Universidade de São Paulo.

E-mail: zeantoniolima@usp.br
Keywords: Egypt. Muslim Brotherhood. Political Islam. Middle East.
RECEBIDO EM: $20 / 11 / 2018$

AProvaDo EM: 10/03/2019 


\section{INTRODUÇÃO}

A "Primavera Árabe", onda de protestos ocorrida em 2010 e 2011, foi equivalente a um abalo sísmico no Oriente Médio. No caso específico do Egito, aquelas manifestações provocaram a queda do regime de Hosni Mubarak (1981-2011), abrindo uma inesperada oportunidade "para os islamistas, que emergiram de décadas de perseguição e foram banidos da política, de adquirir predominância sem precedentes na política" local (PINTO ARENA, 2017). Tal primazia chegou com a mesma rapidez com que ruiu. Em junho de 2012, pouco mais de um ano após o afastamento de Mubarak, Mohammed Morsi, da Irmandade Muçulmana, era o presidente do Egito. Mais um ano passado, em julho de 2013, seu governo foi derrubado e os irmãos muçulmanos estavam novamente sendo perseguidos.

A velocidade dos acontecimentos impediu que se examinasse de modo aprofundado o comportamento, uma vez no poder, dos islamistas, ou seja, os adeptos do islã político, um tipo de pensamento segundo o qual "a religião é um sistema que poderia resolver qualquer problema político, econômico ou social criado pela modernização" (ROY, 2012) e que deriva de uma revolução cultural ocorrida nos 1960, inicialmente tendo como alvo o nacionalismo árabe (KEPEL, 2003). Fundada em 1928, a Irmandade Muçulmana é o grupo mais importante entre os adeptos desta ideologia. Apesar da rápida queda, a Irmandade continua a representar a principal contestação ao regime no Egito e movimentos de matriz ideológica semelhante exercem o mesmo papel em outros países da região. O objetivo deste artigo é, por meio de um exame da história da Irmandade Muçulmana, contextualizar sua existência e contribuir com as análises a respeito do Egito e do Oriente Médio como um todo.

\section{A FUNDAÇÃO E O MITO DE AL-BANNA}

A literatura a respeito da Irmandade Muçulmana enfatiza o papel de seu fundador, Hassan al-Banna, no estabelecimento das principais características do grupo. O destaque à atuação de al-Banna se dá, pois foi no período inicial da Irmandade que os principais traços da personalidade do movimento foram 
estabelecidos. Até hoje, tais características influenciam o comportamento e a visão de mundo dos irmãos muçulmanos.

O início da Irmandade Muçulmana se deu em um momento agitado na sociedade egípcia. O país encontrava-se sob o domínio britânico, iniciado em 1882, de forma "temporária", para garantir interesses europeus no que era uma região com cada vez menos sob influência do Império Otomano: a segurança do Canal de Suez, o pagamento da dívida externa e a segurança dos cidadãos europeus. A ocupação, apesar de trazer alguns avanços, subjugava a população local em nome dos interesses britânicos. A produção local de algodão só poderia ser vendida para as empresas inglesas que tinham exclusividade na venda de tecidos para os egípcios; a criação da indústria têxtil egípcia era bloqueada pelo Reino Unido; o governo investia pouco em educação e se opunha ao uso do idioma árabe, considerado impróprio para o ensino de ciências modernas (GOLDSCHMIDT, 2008).

A partir da virada para o século XX, a ocupação começou a ser firmemente contestada pelo nacionalismo local. Liderados por Saad Zaghlul e pelo partido Wafd, os nacionalistas se insurgiram em 1919, por meio de uma revolução que "produziu significativas mudanças políticas, incluindo uma nova constituição, a proclamação da independência do Egito [em 1922] e um novo governo eleito" (TIGNOR, 2011, p. 244). Neste contexto, Hassan al-Banna criaria a Sociedade dos Irmãos Muçulmanos.

Mitchell (1993) mostra que as experiências pessoais de al-Banna ajudaram a definir dois importantes traços do movimento. Nascido em 1906, em Mahmoudiyah, cidade a cerca de 180 quilômetros a noroeste do Cairo, al-Banna esteve desde cedo envolvido em sociedades religiosas. Em 1923, aos 16 anos, chegou ao Cairo para se tornar professor. Na capital, al-Banna encontrou uma cidade que passava por um momento de grande turbulência, marcado pela "desunião" dos principais grupos políticos da época, pelas orientações de "apostasia e niilismo" do período posterior à Primeira Guerra Mundial e pelo secularismo presente nas universidades, nos livros, nos jornais e nas revistas, assim como estimulado pela revolução de Mustafa Kemal Atatürk (o fundador da Turquia), que acabaria por minar a influência da religião (MITCHELL, 1993). 
Ali, al-Banna começou a ter claro que a sociedade egípcia não era suficientemente religiosa e que apenas a mesquita não bastaria para levar a fé às pessoas (MITCHELL, 1993). Assim, começou a nascer um crucial traço da atuação da Irmandade Muçulmana: a necessidade de usar diversos meios para islamizar a sociedade. Para cumprir este objetivo, al-Banna criou em Ismailia - cidade na região do Canal de Suez, onde a Irmandade Muçulmana foi fundada em 1928 por ele e seis trabalhadores que admiravam seus sermões proferidos em locais públicos - um sistema de estruturação que seria reproduzido em todas as filiais. O sistema consistia no estabelecimento de uma sede, na construção de uma mesquita (com doações e empréstimos conseguidos por al-Banna com seus sermões) e de projetos sociais. Em quatro anos após a fundação, além de Ismailia, a Irmandade Muçulmana estava presente em Port Said, Suez, Abu-Suweir e Shubra Khit (MITCHELL, 1993).

Um segundo traço do movimento foi forjado quando al-Banna deixou o Cairo para assumir uma vaga de professor em Ismailia. Naquela cidade, começou a nascer uma Irmandade Muçulmana cuja existência se constituía em oposição à influência do Ocidente. Ao chegar à Ismailia, al-Banna se deparou com o núcleo da ocupação britânica sobre o Egito, com o que chamou de "ocupação econômica" estrangeira, com a Companhia do Canal de Suez (então controlada pelo Reino Unido) e com a escancarada desigualdade entre as luxuosas casas dos estrangeiros e as moradias miseráveis dos nativos (MITCHELL, 1993). A ampla dominação externa nos campos político, econômico e militar era questionada por diversos movimentos egípcios. Para a Irmandade Muçulmana, esses problemas eram resultado da propagação de valores e práticas seculares ocidentais:

Os modelos seculares de direito e educação emprestados da Europa estavam fora de sintonia com as crenças e sentimentos religiosos da sociedade egípcia; da mesma forma, o conteúdo "barato", "lascivo" e "sugestivo" da mídia, dos filmes e da música minavam os valores tradicionais e criavam problemas morais e sexuais para a juventude. (WICKHAM, 2013, p. 22) 
A dominação interna, por parte da elite, também era explicada por al-Banna a partir da lógica anti-imperialista. Segundo ele, o "colonialismo interno" era levado a cabo pelas elites egípcias, que se beneficiavam da presença dos britânicos e tinham objetivos semelhantes aos deles (RUTHERFORD, 2008). Com esta forma, o antiocidentalismo da Irmandade Muçulmana tinha grande apelo para o Egito do início do século XX, pois a mensagem de al-Banna de que o islã deveria estar presente não somente na mesquita, mas na sociedade como um todo, "habilmente tocou a preocupação das pessoas com a erosão da tradição e a crescente ocidentalização da elite egípcia, além da atitude aparentemente quiescente do establishment religioso oficial" (PARGETER, 2013, p. 20).

É importante ter em conta que, neste momento da história do Egito, a Irmandade Muçulmana surgia como apenas uma das alternativas na batalha ideológica travada para definir o futuro do país. Os easternists, apoiados pelo palácio real, vislumbravam aproveitar o vácuo deixado pelo Império Otomano para aproximar o Egito do Oriente Médio e torná-lo um líder da região. Este projeto não tinha muita aceitação, pois não entrava em consonância com a experiência pregressa do país, uma vez que a maior parte dos egípcios se considerava menos oriental ou mesmo árabe do que se considerava muçulmana (OSMAN, 2011).

A outra força ideológica daquele período era o liberalismo, capitaneado pelo Wafd. O partido teve papel proeminente na independência do Egito (que se deu oficialmente em 1922), lutou contra a família real para estabelecer uma monarquia constitucional aberta ao capitalismo e a liberdades civis, bem como desejava "colocar o Egito na Europa" (OSMAN, 2011). Foi este projeto que ampliou no Egito o espaço para a efervescência cultural ocidental, vista com preocupação por al-Banna.

Neste contexto de disputa política e social, a Irmandade Muçulmana precisava fazer avançar seu projeto de sociedade e, ao mesmo tempo, garantir a existência do grupo. Desta dinâmica, emergiu uma terceira característica importante do movimento: o pragmatismo de sua liderança. Para Pargeter (2013), este aspecto é reflexo do estilo pessoal de al-Banna, um líder sempre ciente da necessidade de os irmãos muçulmanos terem um "entendimento 
com os poderes estabelecidos", ainda que este fosse considerado "não-islâmico" (PARGETER, 2013, p. 25 - 26). A flexibilidade de al-Banna se manifestava de diversas maneiras no nível pessoal, como em concessões religiosas a homens ricos que poderiam ajudar a causa da Irmandade ou na escolha da vestimenta (fosse um terno ou uma tradicional jellabiya), adequada para provocar o máximo impacto na audiência escolhida para seus sermões (PARGETER, 2013). Foi, entretanto, quando a Irmandade Muçulmana passou a se engajar com mais afinco na política egípcia que o pragmatismo do grupo ficou em maior evidência.

Em 1932, al-Banna conseguiu ser transferido de Ismailia para o Cairo, de onde passou a liderar a Irmandade. O grupo se expandiu e passou a ser representado em quase todos os setores da sociedade, se tornando, no fim da década de 1940, um dos mais importantes atores da cena política egípcia (MITCHELL, 1993). Por meio de conferências nacionais, sempre lideradas por al-Banna, a Irmandade estabelecia suas regras, como a obediência aos líderes; criava novas formas de comunicação, como revistas, boletins e jornais; e articulava sua ideologia. Em 1939, na quinta conferência anual, a Irmandade passou a almejar "uma nova vida" e "uma nova luta" e decidiu que estava suficientemente preparada para se tornar uma "organização política" (MITCHELL, 1993, p. 16). O novo projeto encontrou resistências e al-Banna foi obrigado a negociar com os poderes estabelecidos.

Um episódio emblemático ocorreu nas eleições parlamentares de 1942, quando 17 irmãos muçulmanos, incluindo o próprio al-Banna, se lançaram como candidatos. Por pressão do então primeiro-ministro, Mustafá Nahas Pasha, que usou como justificativa o "estado de guerra" em que o Egito se encontrava por conta da Segunda Guerra Mundial, al-Banna aceitou recuar e ainda publicar um texto no qual prometia lealdade ao Tratado AngloEgípcio de 1936, que previa a manutenção de tropas britânicas no Egito e que havia sido denunciado pela Irmandade em 1938 e 1939. O Conselho de Orientação da Irmandade Muçulmana recusou as exigências, mas al-Banna decidiu aceitar. Em troca, obteve o direito de viajar para fora do Cairo sem pedir autorização ao Ministério do Interior, uma exigência que havia sido imposta 
a ele (TADROS, 2012), e a promessa de que o governo iria tomar providências quanto à venda de álcool e à prostituição no Egito (PARGETER, 2013). Como afirma Pargeter (2013, p. 23), isso deixa claro que al-Banna não era avesso à ideia de integrar o establishment político "de forma a avançar os objetivos da Irmandade mesmo que isso contradissesse seus próprios ensinamentos e ideologia" e estava disposto a ir longe para ganhar peso político.

Apesar da disposição de al-Banna para negociar, a entrada da Irmandade na política não foi suave e serviu como combustível para inflamar ainda mais a década de 1940 no Egito. Se nos anos 1930 os irmãos muçulmanos eram usados pelo palácio real para contrapor o peso do Wafd, o mais popular partido da época, na década de 1940, eles passaram a disputar influência nos rumos do país. Esta contenda nem sempre se deu por meios legais e foi marcada tanto por ataques verbais, feitos por meio da imprensa e de discursos, quanto pela violência física de cunho político, na qual atuavam com destaque grupos paramilitares do Wafd (Camisas Azuis), do partido ultranacionalista Jovem Egito (Camisas Verdes) e os da Irmandade Muçulmana, os escoteiros (jawala), grupos criados a partir do treinamento atlético da Irmandade (MITCHELL, 1993), e os batalhões (kata'ib). Como afirma Mitchell (1993, p. 314), o surgimento desses grupos, inspirados em facções fascistas europeias do entre guerras, coincidiu com as "manipulações extra-legais dos processos constitucionais pelo palácio".

A Segunda Guerra Mundial agravou a situação. Durante o conflito, o Egito teve quatro trocas de primeiro-ministro. Era uma época em que o Reino Unido fazia diversas intervenções de forma a instalar um premiê capaz de garantir estabilidade, em um dos principais fronts do conflito fora da Europa. A estabilidade veio somente em fevereiro de 1942, com o governo liderado pelos liberais do Wafd. No fim da guerra, a situação econômica do Egito era marcada por desemprego alto e inflação galopante, entre outros problemas. A luta por independência definitiva do Reino Unido e a questão palestina, cada vez mais saliente, acirravam a briga entre os grupos políticos e entre esses e o palácio. Bastião do nacionalismo no início do século XX, o Wafd saiu enfraquecido da Segunda Guerra, por ter liderado o governo de apoio aos britânicos, e a Irmandade cresceu em importância. 
Ocasionalmente, o movimento de al-Banna realizou alianças com o Wafd e com o palácio, mas elas não sobreviveram às diferenças entre os grupos. Num período que Mitchell (1993, p. 59) define como "o começo da fase final do colapso da vida parlamentar e do estado de direito no Egito", assassinatos políticos, atentados à bomba e incêndios criminosos se tornaram comuns de lado a lado. Percebida como ameaça, a Irmandade foi dissolvida em 8 de dezembro de 1948 pelo governo do então premiê Mahmud Fahmi al-Nuqrashi Pasha. No dia 28 do mesmo mês, al-Nuqrashi foi assassinado por um integrante do "aparato secreto" da Irmandade, uma unidade separada de sua estrutura principal. Em fevereiro de 1949, em meio a uma intensa repressão imposta pelo governo de Ibrahim Abd al-Hadi, veio a vingança: al-Banna foi executado pela polícia política a mando do novo premiê egípcio (MITCHELL, 1993).

\section{A PERSEGUIÇÃO SOB NASSER}

Na empreitada contra a influência britânica e ocidental no país, a Irmandade tinha interesses comuns com os militares, em especial um grupo nacionalista que viria a ser conhecido como Oficiais Livres. À medida que foi ficando óbvio que a monarquia, então sob o rei Farouk, e os governos designados por ela não romperiam de uma vez com o Reino Unido, os militares e a Irmandade Muçulmana não só tinham um interesse em comum como se tornaram aliados muito próximos.

Mitchell (1993) mostra que militares treinavam irmãos muçulmanos em campos públicos, montados em universidades, escolas secundárias e também em locais privados, bem como afirma que os contatos entre a Irmandade e os oficiais tiveram importância histórica, pois serviram, entre outras coisas, para a "encorajar Al-Banna a prosseguir com seus próprios planos para [realizar] atividades secretas revolucionárias" (MITCHELL, 1993, p. 96).

As pressões contra a monarquia, que se arrastavam por décadas, chegaram ao ápice em 23 de julho de 1952, com a derrubada do rei Farouk. Uma vez no poder, os militares fizeram diversos acenos aos irmãos muçulmanos. Como recorda Mitchell (1993), o novo regime aboliu a polícia secreta do Ministério do Interior, 
responsável pela morte de al-Banna, determinou uma investigação imediata daquele assassinato e, ao dissolver todos os partidos por decreto, manteve a Irmandade Muçulmana em funcionamento. Em ato ainda mais simbólico, Nasser e o general Mohamed Neguib, líder do golpe, participaram da peregrinação ao túmulo de al-Banna em fevereiro de 1953, no quarto aniversário de sua morte (MITCHELL, 1993).

Os irmãos muçulmanos, entretanto, não tinham controle sobre as ações dos militares, muito menos sobre as de Nasser, que se tornaria o líder máximo da revolução. Nasser percebia os irmãos muçulmanos como um grupo pouco fiel a ele, enquanto a Irmandade não via em Nasser o líder que imaginara antes. Assim, rapidamente a relação se deteriorou. Em janeiro de 1954, foi determinada a dissolução da Irmandade. Em 27 de outubro de 1954, Mahmoud Abdel Latif, com o auxílio de integrantes da Irmandade, mas não com a anuência da liderança (MITCHELL, 1993, p. 149 151), tentou assassinar Nasser em Alexandria.

A partir dali, e até 1970, a Irmandade permaneceu como um "alvo primordial" do governo Nasser (WICKHAM, 2013). A perseguição teve início imediatamente após a tentativa de assassinato, com saques e incêndios na sede do grupo no Cairo e em escritórios no interior. Com seus discursos, Nasser conseguiu retratar a Irmandade como uma força contrarrevolucionária, impressão estimulada pelos julgamentos de diversos integrantes em "tribunais populares" e pela campanha da imprensa contra o grupo. Na mídia, afirma Mitchell (1993, p. 152), surgiram "'evidências' de que os irmãos eram agentes e lacaios da monarquia, da antiga classe dominante, dos britânicos, dos franceses, dos sionistas, do imperialismo ocidental, do comunismo e do capitalismo". Sob ordens de Nasser, milhares de irmãos muçulmanos foram perseguidos, presos e torturados.

É importante ter em conta que Nasser e a Irmandade Muçulmana não tinham apenas diferenças políticas pontuais. Elas eram também ideológicas. Nasser teve um retorno "triunfal" de Alexandria para o Cairo (MITCHEL, 1993), após a tentativa de assassinato e logo deixou de ser uma figura sombria para se transformar em um "corajoso e amado filho do Egito" (COOK, 2012, p. 64). 
Com ele no comando, os Oficiais Livres transmitiam a percepção de que "estavam cumprindo suas promessas de lidar com as injustiças sociais, promover o desenvolvimento econômico e tornar o Egito uma potência regional" (COOK, 2012, p. 64). Nasser realizou profundas transformações no Estado egípcio, caracterizadas pela substituição do modelo econômico liberal por um modelo socialista; pela abrangente reforma agrária, que colocou fim ao sistema feudal ainda vigente no Egito; e pela criação de um imenso setor público que tinha como função primordial administrar as inúmeras fábricas e companhias estatais que englobavam virtualmente todos os negócios significativos da economia (OSMAN, 2011).

A nacionalização do Canal de Suez, em 1956, contra os interesses de Reino Unido, França e Israel, catapultou Nasser para um nível de admiração transcendental, uma veneração "indiscutivelmente superior do que as de qualquer líder político desde o profeta Maomé" (OSMAN, 2011, p. 51). Como afirma Osman (2011, p. 51), ao nacionalizar o canal, Nasser estava "afirmando o orgulho nacional; enfrentando as potências imperialistas que dominaram a região por décadas; libertando emocionalmente milhões de árabes e egípcios oprimidos".

Nasser se tornou um mito, mas seu projeto era civil, não islâmico. Ele considerava a religião muçulmana como "um quadro civilizacional para seu projeto árabe nacionalista" (OSMAN, 2011, p. 60), mas repudiava o islã como forma de governo. Na luta contra Israel em 1948, Nasser esteve ao lado tanto de muçulmanos quanto de cristãos e "seu povo" se definia como árabe e não simplesmente como muçulmano (OSMAN, 2011, p. 63). O regime de Nasser conseguiu forjar uma identidade árabe que, por algum tempo, teve sucesso em suplantar a identidade egípcia relacionada com o período anterior, de liberalismo influenciado pela Europa. A busca pela "arabização" por parte de Nasser mirava não somente o Egito, mas todo o entorno. Como afirma Osman (2011), havia uma clara preocupação em não alienar comunidades cristãs importantes, como a existente no Líbano; portanto, a sociedade não era retratada pelo Estado como sendo religiosa, mas sim secular, uma prática escancarada pelo aparato de comunicação estatal, cuja retórica "glorificava as pessoas, a nação, 'nossa história 
árabe' e se distanciava de qualquer linguagem ou simbolismo religioso" (OSMAN, 2011, p. 166).

A derrocada de Nasser e do nacionalismo árabe começou a se dar por conta da projeção de poder realizada por ele a partir do Egito. A expansão da influência egípcia criava perigos para três importantes atores estratégicos do Oriente Médio: a Arábia Saudita, os Estados Unidos e Israel. Os sauditas representavam um regime monárquico e teocrático, projeto amplamente antagonista ao de Nasser, e que o via como inimigo. Os norte-americanos também percebiam em Nasser um grande perigo, pois ele, além da proximidade com a União Soviética, era capaz de unificar os povos do Oriente Médio e de controlar essa região estratégica, assim como as fontes de petróleo e as rotas comerciais. Israel, por sua vez, via a ameaça de Nasser como "fatal", pois ele retratava o conflito contra o Estado judeu como um a ser travado por todos os árabes e não apenas pelos palestinos. Nasser via Israel como uma "base militar ocidental" no coração do mundo árabe, cuja função era dividi-lo (OSMAN, 2011, p. 71).

Neste ambiente, Nasser travou a Guerra dos Seis Dias (1967) contra Israel, na qual as forças israelenses tiveram uma vitória militar espetacular: as tropas egípcias e sírias foram quase completamente destruídas e Israel ocupou a Cisjordânia, a Faixa de Gaza, a Península do Sinai, as Colinas de Golã e Jerusalém. A derrota acachapante marcou o que Osman (2011, p. 73) chama de "fim do projeto nasserista". A partir dali e até sua morte em 28 de setembro de 1970, Nasser seria uma sombra de si mesmo.

\section{A ABERTURA DE SADAT}

A morte de Nasser abriu espaço para a reorganização da Irmandade. Isso ocorreu, em grande medida, por conta do projeto político do novo presidente, Anwar al-Sadat, outro militar.

Sadat teve papel ativo no grupo que derrubou a monarquia em 1952 e, durante os preparativos para a revolução, manteve diversos contatos com al-Banna, por meio dos quais buscava arregimentar os irmãos muçulmanos para a campanha contra a monarquia. Uma vez instalado o governo militar, Sadat passou a integrá-lo e, 
na disputa política deste com a Irmandade, teve atuação destacada como "principal voz do governo na batalha por meio da imprensa" com os irmãos muçulmanos (MITCHELL, 1993, p. 143).

Sadat assumiu a presidência em 15 de outubro de 1970 e dedicou seu mandato a mudar os rumos do Egito e "corrigir a revolução". Três projetos foram marcantes nesta empreitada. O primeiro foi a chamada Guerra do Yom Kippur (1973), que teve como resultado acabar com a humilhação, do ponto de vista egípcio, configurada pela ocupação israelense na Península do Sinai. O Egito experimentou mais uma derrota militar nas mãos de Israel naquele confronto, mas, ainda assim, a guerra teve um efeito positivo profundo no Egito, de retomada do orgulho nacional.

Os outros dois projetos de Sadat para romper com o legado de Nasser estavam interligados, mas só puderam ser colocados em prática depois da guerra, porque ele tinha o "capital político e a coragem" para romper com o Nasserismo (OSMAN, 2011, p. 129). Um dos projetos era a reorientação política do Egito, que deixaria a órbita de influência da União Soviética para aderir ao bloco liderado pelos Estados Unidos. Neste processo seria fundamental a paz com Israel, baseada no "ódio ao belicismo das décadas de 1950 e 1960" (OSMAN, 2011, p. 129), desenvolvido por Sadat, e na crença de que o confronto de 1973 deveria ser o último entre Egito e Israel. O terceiro projeto foi a reorientação econômica do Egito, a abertura (infitah). Como afirma Rutherford (2008), a fraqueza do estatismo da era Nasser tinha ficado clara após a Guerra dos Seis Dias, quando, para refazer as Forças Armadas, milhões de libras egípcias deixaram de ser aplicados em investimentos econômicos produtivos. Da mesma maneira, afirma Rutherford (2008), a política externa de Nasser servia para isolar o Egito e reduzir seu acesso a financiamentos e tecnologia moderna. Para romper com este ciclo, Sadat buscou abrir o Egito para capitais estrangeiros e um comércio mais livre.

O plano de Sadat falhou ao atrair investimentos norte-americanos, europeus e japoneses, mas conseguiu concretizar um interesse do Irã e de países árabes ricos em petróleo na economia egípcia. Inicialmente, Sadat desfrutou de grande popularidade. Os Estados árabes passaram a emprestar dinheiro ao Egito, bancos internacionais 
voltaram a operar no país, as classes favorecidas conseguiram realizar os sonhos de ter um carro importado e um apartamento de luxo, Cairo e Alexandria se tornaram canteiros de obras e cidades destruídas nas guerras, como Port Said, Ismailia e Suez - na região do canal - foram reconstruídas (GOLDSCHMIDT, 2008). Os resultados da abertura, entretanto, beneficiavam apenas a elite.

A governadoria do Cairo gastou muito para construir pontes e avenidas para beneficiar a minoria de sua população que podia ter carro ou pagar por um táxi, enquanto negligenciou a necessidade da maioria, um transporte público melhor, especialmente nos bairros mais pobres. Para os camponeses, a infitah significou o fim da reforma agrária, a deterioração dos serviços das cooperativas agrícolas e dos centros de saúde e o declínio dos termos de pagamento pela colheita. [...] camponeses, engenheiros, médicos, professores, encanadores e eletricistas foram para outras terras árabes para ganhar salários maiores. [...] no longo prazo, isso separou famílias, provocou novas desigualdades salariais e falta de trabalhadores especializados nas zonas urbana e rural. (GOLDSCHMIDT, 2008, p. 198; 199).

Este foi um momento crucial na história do Egito, pois fez com que o regime passasse a ter uma nova e poderosa base de apoio, uma classe capitalista formada por seus aliados e apadrinhados, majoritariamente ex-militares e ex-oficiais da inteligência estatal, beneficiados pelas novas oportunidades econômicas (OSMAN, 2011). Ao mesmo tempo em que a elite era beneficiada e se constituía em uma força política formidável para o regime, as camadas mais desfavorecidas da população sofriam. Com a abertura, o governo passou a desfazer lentamente a sua rede de proteção social. Os novos serviços privados de educação, saúde e habitação eram direcionados a quem podia pagar, enquanto "aqueles na periferia da economia, com habilidades menos vendáveis, aposentados e a grande maioria dos funcionários públicos de baixo escalão estavam efetivamente caindo na pobreza" (OSMAN, 2011, p. 134).

À medida que se abria um vácuo deixado pelo Estado, ele era preenchido pelas atividades humanitárias da Irmandade Muçulmana, que continuavam funcionando e ganhavam corpo 
devido à maior necessidade daqueles tempos. Para Osman (2011, p. 93), a eficiência deste trabalho social foi o fator que "realmente cimentou a reemergência social da Irmandade e fundou a base social do movimento":

Isso incluía uma gama de provisões direcionadas aos pobres e necessitados: cuidados de saúde a preços acessíveis, centros "não-corruptos" de distribuição de comida em bairros pobres, assistência para encontrar empregos (direcionado especialmente a muçulmanos recém-formados), benefícios sociais, soluções inovadoras de transporte em alguns dos subúrbios mais populosos do Cairo e de Alexandria, acomodação para estudantes que estavam fora de suas cidades (além de resumos de aulas e grupos de estudo) e atividades humanitárias em algumas das áreas mais desprovidas do Egito. (OSMAN, 2011, p. 93)

Também sob o governo Sadat, a Irmandade conseguiu se tornar novamente um ator político relevante. Isto se deu, devido à outra faceta da tentativa de Sadat de se afastar do Nasserismo: além da abertura econômica, ele procurou romper a completa eliminação do papel da religião na sociedade imposta por seu antecessor. Para isso, buscou estabelecer o islã como "fundação primária da ordem política" (WICKHAM, 2013, p. 31). Para contrabalançar o poder de esquerdistas e nasseristas, deu mais força aos movimentos religiosos, percebidos por ele como menos perigosos (GOLDSCHMIDT, 2008). A estratégia foi composta por diversos atos, um dos quais beneficiaria diretamente a Irmandade Muçulmana. O grupo recebeu uma anistia geral e, entre 1971 e 1975, seus integrantes foram libertados (WICKHAM, 2013).

A guinada em direção à religiosidade promovida por Sadat tornou a década de 1970 uma das mais importantes para a história do islã político. A perseguição sofrida sob Nasser esfacelara a Irmandade. A libertação de muitos líderes por Sadat e o crescimento dos serviços sociais não seriam suficientes para fazer o grupo retomar sua força política, então era preciso ampliar o número de integrantes. A principal estratégia para tanto foi buscar o apoio de grupos estudantis que passaram a se coordenar de forma independente sob o manto de uma organização guarda-chuva conhecida 
como Grupo Islâmico. Esta facção ganhou popularidade ao lidar com "problemas reais de estudantes marginalizados economicamente e socialmente conservadores que tinham problemas para se ajustar ao ambiente universitário" (WICKHAM, 2013, p. 35 - 36). Em pouco tempo, passaram a conquistar vitórias em eleições para grêmios universitários até se tornarem (com a anuência de Sadat, preocupado também com os estudantes nasseristas e esquerdistas) a força dominante entre as entidades estudantis.

Os irmãos muçulmanos encorajavam abertamente a atuação do Grupo Islâmico e davam publicidade a ela por meio de suas publicações (WICKHAM, 2013). Isso criou um contato entre os dois movimentos que, após alguns anos de negociação, culminou na adesão de muitos líderes estudantis à Irmandade. Segundo Wickham (2013) e Pargeter (2013), a união foi fundamental para renovar a força da Irmandade, após anos de ausência na vida política do Egito. Em entrevista a Pargeter (2013, p. 43), Abu Elela Mady, uma das principais figuras que deixou o Grupo Islâmico para a Irmandade, afirmou que, sem os líderes estudantis, a Irmandade "teria morrido".

Em paralelo à tentativa de renovar seus quadros com os estudantes, a velha guarda da Irmandade, então liderada por Umar al-Tilmisani, terceiro guia supremo (murshid), tinha outras estratégias para retomar seu papel político, nomeadamente a participação nas eleições parlamentares e a formação de uma aliança tática com o governo Sadat. Havia dois interesses por trás do acordo com o regime. O primeiro era compartilhado com o governo - a contenção do nasserismo, encarado como o principal movimento de oposição ao islã político - e o segundo era egoísta - a busca pela preponderância dentro da corrente islamista (BAKER, 1990). Como afirma Wickham (2013, p. 30), al-Tilmisani consolidou a abordagem gradualista de seu antecessor, Hassan al-Hudeibi, a respeito da reforma islâmica da sociedade e "deixou patentemente clara a rejeição da Irmandade às ações violentas contra o Estado". Este gradualismo e a atuação parlamentar dos irmãos muçulmanos, voltada à islamização da sociedade, colocaram o movimento em conflito ideológico com os elementos mais radicais do Grupo Islâmico.

Enquanto uma parte dos líderes estudantis passou a rejeitar a política pacificamente (os salafistas) e outra adotou a visão 
gradualista de reforma da Irmandade, muitos enveredaram por um terceiro caminho, o do jihadismo. Adeptos de Sayyid Qutb, pensador cujas ideias justificam o uso da violência contra aqueles considerados "infiéis", eles formaram diversas células militantes islâmicas que se engajaram em atos violentos contra o Estado. Na competição pela fidelidade dos estudantes, líderes da Irmandade, incluindo o próprio al-Tilmisani, passaram a participar de seminários e conferências do Grupo Islâmico, nos quais "Os objetivos e métodos da Irmandade, retratados como sendo baseados em entendimentos 'adequados' e 'corretos' do islã, em contraposição às visões 'equivocadas' dos jihadistas”' (WICKHAM, 2013, p. 40). Esta atuação era feita em coordenação com o regime de Sadat, como admitiu o próprio al-Tilmisani, ao afirmar que era enviado às universidades pelo então ministro do Interior do Egito, Nabawy Ismail, a quem também dava conselhos sobre como lidar com os islamistas mais radicais (BAKER, 1990).

A aliança entre Sadat e a Irmandade Muçulmana, entretanto, não era completa. Além das críticas feitas ao governo por conta da situação econômica precária do Egito, a Irmandade (e toda a corrente islâmica) divergia profundamente da política externa de Sadat. Ao perseguir uma aproximação com os EUA - que "exportavam" os hábitos ocidentais para as elites muçulmanas - e buscar a paz com Israel, visto como responsável pelo sofrimento dos palestinos, Sadat percorreu um caminho que os islamistas não poderiam aceitar.

A Irmandade, então, passou a fazer críticas abertas ao governo por conta da questão palestina, central na ideologia do movimento. Percebendo a crescente precariedade da aliança tática com os irmãos muçulmanos, Sadat vetou em 1979 a formação de um partido político ligado ao movimento, um pedido levado ao presidente egípcio pessoalmente por al-Tilmisani (WICKHAM, 2013). Nos anos seguintes, Sadat adotou tom combativo contra o islã político como um todo e contra a Irmandade em particular, bem como passou a defender a "total separação entre religião e política", discurso cuja intenção era "continuar livre para manipular a religião para referendar suas políticas ao mesmo tempo em que bloqueava seu uso por seus oponentes" (WICKHAM, 2013, p. 33). Acuado, Sadat 
ordenou, em 5 de setembro de 1981, a prisão de 1,5 mil opositores, entre intelectuais, políticos e religiosos, incluindo centenas de islamistas. De nada adiantou a repressão. Na parada militar de 6 de outubro de 1981, Sadat foi assassinado pelo militar Khalid Islambouli, integrante de uma conspiração realizada pela al-Jihad.

\section{A DEMOCRATIZAÇÃO COSMÉTICA DE MUBARAK}

O sucessor de Sadat foi seu vice-presidente, o ex-comandante da Força Aérea Hosni Mubarak, cujo governo seria caracterizado pelo aprofundamento do processo de abertura da economia para o setor privado e por ondas de abertura política, sempre seguidas por fases de dura repressão, sem que houvesse uma democratização genuína.

Ao contrário de Sadat, que procurou deixar claras as diferenças diante de Nasser, Mubarak deu continuidade a algumas políticas de seu antecessor. A principal delas foi aprofundar a infitah, processo que permitiu a expansão do império econômico montado por ex-militares e ex-oficiais de inteligência graças à proximidade com o Estado. Institucionalizado sob Sadat, o poder econômico dos militares foi muito ampliado sob Mubarak. Como não há supervisão civil do orçamento militar, não se sabe o real tamanho deste império, mas estimativas variam de $8 \%$ a $40 \%$ do Produto Interno Bruto do Egito (LIMA, 2014).

A estratégia de desenvolver um "capitalismo de compadrio" produziu uma complexa simbiose entre o poder e o dinheiro no Egito. Integrantes das elites econômica e política, os militares se tornaram subservientes à Presidência, mas, em troca, conseguiram preservar o que Kurtzer e Svenstrup (2012) chamam de "três interesses corporativos chave": a imagem de principal ente patriótico do Egito (uma herança nasserista), o papel de garantidor das fronteiras nacionais e a manutenção dos negócios militares sem supervisão civil.

Contudo, a liberalização da economia feita por Mubarak não beneficiou somente os militares. Apesar do grande investimento do regime na infraestrutura do país nos anos 1980, o Egito chegou ao fim da década em uma situação econômica precária. 
Doadores e organizações internacionais estavam dispostos a emprestar dinheiro para o governo do Cairo, mas, em troca, o país teve de entrar, em 1991, no Plano de Reforma Econômica e Ajuste Estrutural do Fundo Monetário Internacional (RUTHERFORD, 2008), que preconizava a privatização de empresas públicas.

Neste período, famílias e grupos privados com redes de contatos privilegiadas conseguiram se beneficiar da proximidade com o Estado e ficaram com boa parte do um terço de companhias estatais privatizadas pelo governo, entre 1991 e 2000 (RUTHERFORD, 2008, p. 198). Transformados em empresários extremamente ricos da noite para o dia, esses investidores buscaram formas de garantir seus interesses. A estratégia encontrada para tanto foi uma aliança política com Gamal Mubarak, filho de Hosni, que ascendeu na estrutura do Partido Nacional Democrático (conhecido pelo acrônimo em inglês NDP) e do governo.

O neoliberal e ocidentalizado Gamal formou, com o auxílio de alguns dos principais capitalistas do Egito, um comitê de políticas públicas no NDP que se tornou o motor e centro de gravidade do partido (OSMAN, 2011). Graças a Gamal, "pela primeira vez na história moderna do Egito a elite empresarial está [estava] tendo um papel na questão da sucessão" (ROLL, 2010, s/paginação). Ao contrário de Nasser, Sadat e do pai, Gamal não se sustentava no establishment militar ou de inteligência; quase todos os seus aliados vinham dos altos escalões empresariais civis. A impressionante ascensão do neoliberalismo personificado por Gamal, apontado como sucessor de Mubarak, o colocaria em oposição aos interesses dos militares.

A primeira onda de abertura política de Mubarak se deu logo após a sua posse do governo do Egito. No início dos anos 1980, Mubarak libertou milhares de prisioneiros de diversos grupos políticos, relaxou a censura sobre a imprensa, permitiu que os sindicatos profissionais se tornassem atores sociais e políticos relevantes e realizou eleições parlamentares que, ao menos nominalmente, permitiam certo grau de pluralismo (OSMAN, 2011). Tendo acompanhado de perto o governo Sadat, Mubarak tinha consciência da força do islã político, mas, ao contrário de seu antecessor, não buscou manobrar os islamistas contra outras forças sociais. Em vez disso, optou por diferenciar os elementos mais moderados dos mais radicais, dando legitimidade aos primeiros de modo a conseguir controlá-los. 
Dos grupos mais militantes, que viam na violência o único meio de combater o governo, Mubarak cuidava com a Lei de Emergência, que autorizava o Estado a prender cidadãos sem ordem judicial, impedir reuniões e governar por decreto. A estratégia não deu certo. No fim dos anos 1980, a política flexível de Mubarak, "que falhou ao cooptar ou silenciar efetivamente a oposição islâmica, deu lugar a uma resposta mais agressiva ao desafio tanto dos extremistas religiosos [...] quanto dos moderados" (ESPOSITO; VOLL, 1996, p. 177). Nesta empreitada, não apenas facções violentas eram perseguidas, mas também a Irmandade Muçulmana.

Nos anos 1990, o Egito experimentou uma onda de violência política sem precedentes, cujas origens estão na divisão interna do islã político. Após duas décadas de experiência em sua guerra contra o regime, facções radicais como al-Jihad, o Grupo Islâmico (homônimo da "entidade guarda-chuva" dos anos 1970) e a Sociedade dos Muçulmanos estavam extremamente organizadas nos anos 1990. Ibrahim (1999) nota que muitos dos integrantes desses grupos atuaram como mujahideen no Afeganistão e voltaram de lá com uma experiência que permitia a realização de ofensivas mais longas e sofisticadas do ponto de vista militar. A preparação tornou os movimentos extremistas mais ousados. Entre seus alvos estiveram militares de alta patente, ministros e políticos importantes, incluindo o próprio Mubarak. Os militantes islâmicos, entretanto, também atacavam alvos civis, como "cristãos coptas, pensadores muçulmanos seculares, turistas estrangeiros e/ou objetivos que consideravam repugnantes, como cinemas, cafés, locadoras e cruzeiros no Nilo" (IBRAHIM, 1999, p. 38).

Mubarak tinha o apoio de grande parte da população na repressão violenta contra o terrorismo, mas não conseguiu transformar essa batalha em um projeto nacional que incluísse uma busca para desenvolver o Egito do ponto de vista social (OSMAN, 2011). Ao lidar com os problemas do islã político como uma questão meramente de segurança e ignorar o componente social da crise, o regime abriu um enorme espaço para a versão não violenta do islamismo, nomeadamente a Irmandade Muçulmana, e plantou as bases da instabilidade que levariam ao fim de seu mandato.

As reformas econômicas de Mubarak não apenas ampliaram o império dos militares, como também criaram uma poderosa classe 
empresarial civil. Elas aprofundaram a desigualdade social. Na década de 1990, a economia egípcia foi marcada por desemprego em alta, inflação de dois dígitos e um brutal aumento do custo de vida para os mais pobres e para grandes setores da classe média. Tal situação era duplamente ruim para o regime, pois servia como combustível tanto para os grupos islamistas violentos quanto para a Irmandade Muçulmana. O estudo estatístico de Ibrahim (1999) mostra que os militantes das facções islamistas violentas eram mais jovens (com média de idade de 21 anos) e tinham menos educação formal (apenas 20\% eram universitários) que os integrantes de movimentos similares atuantes no Egito em décadas passadas. Muitos deles vinham das regiões desprovidas de estrutura, como áreas rurais, pequenas cidades e favelas urbanas, algumas delas sem qualquer sinal de presença do Estado e dominadas por longos períodos por grupos violentos (IBRAHIM, 1999). Esse perfil socioeconômico mostra que os sentimentos de alienação e descontentamento tinham se espalhado para os egípcios mais jovens e menos educados, o que, em parte, poderia explicar a disposição para usar violência letal (IBRAHIM, 1999).

Ao mesmo tempo em que abastecia os movimentos violentos com recrutas, o vácuo deixado pelo Estado servia para grupos mais moderados, como a Irmandade Muçulmana, ampliarem sua base social. Diante da falência do Estado, as organizações islâmicas se tornaram, nos anos 1990, "agentes efetivos de mudança social e política, desenvolvendo instituições socioeconômicas alternativas e participando do processo político, demonstrando sua força na construção de instituições e mobilização popular" (ESPOSITO; VOLL, 1996, p. 178).

Ao desenvolver seu aparato social e demonstrar capacidade administrativa ao longo dos anos, a Irmandade gerou um capital político significativo que foi coletado pelo grupo nas eleições parlamentares de 2005, quando os irmãos muçulmanos, concorrendo como "independentes", ficaram com 88 das 454 cadeiras disputadas. Aquele resultado, entretanto, abriria as portas para mais repressão contra os islamistas.

No início da década de 2000, a política externa dos Estados Unidos foi profundamente marcada pelos ataques de 11 de 
Setembro de 2001. O episódio serviu para reformular algumas práticas de Washington, que passaria a atuar para "exportar" democracia para o Oriente Médio. A iniciativa, entretanto, era hesitante e deu origem ao que Ottaway e Dunne (2007) chamaram de "democratização cosmética" do Oriente Médio, um processo caracterizado por reformas feitas de cima para baixo, que permitiam aos governantes projetar uma imagem de mudança sem realizar redistribuição de poder significativa.

Como a pressão se dava de forma inconsistente e fragmentada, não havia incentivos para uma democratização genuína. O governo Mubarak foi um exemplo claro deste processo. Pressionado por Washington, ele abriu a possibilidade de a eleição presidencial de setembro de 2005 ter mais de um candidato (além dele próprio) e relaxou a repressão antes do pleito parlamentar, marcado para novembro e dezembro do mesmo ano. Mubarak venceu a eleição presidencial, marcada por inúmeras fraudes, mas a Irmandade obteve seu bom resultado de 88 cadeiras no pleito legislativo. Ocorre que a emergência dos irmãos muçulmanos, somada à vitória do Hamas nas eleições palestinas de janeiro de 2006, acabou por interromper a campanha por democratização no Oriente Médio, uma vez que ficara claro para Washington que mesmo uma mínima abertura democrática nos países da região colocaria o islã político em um papel de destaque. Ali acabaria o ímpeto da democratização, ainda que cosmética, promovida pelos Estados Unidos.

As iniciativas de Mubarak para democratização provavelmente só funcionariam para conter a instabilidade no Egito se fossem amplas e irrestritas. Nos anos 2000, a severa desigualdade social do país chegou "a novos extremos", representados pelo fato de $40 \%$ da população viver abaixo da linha da pobreza enquanto os 5\% mais ricos eram responsáveis por movimentar todos os setores da economia que não a compra de produtos alimentícios básicos (OSMAN, 2011 ). Neste período, a desigualdade se tornou também mais aparente, graças ao boom populacional nas grandes cidades egípcias, como o Cairo e Alexandria, onde os ricos passaram a trocar as regiões centrais da cidade por condomínios fechados em áreas afastadas.

Também durante este momento ficou mais visível a aliança entre o poder e o dinheiro no Egito, com a ascensão da 
classe empresarial civil que tinha em Gamal Mubarak seu principal símbolo. A cada vez mais certa sucessão hereditária que se avizinhava, com Gamal no lugar de Hosni Mubarak, adicionava certo grau de humilhação para a população. Também durante esta época, a corrupção e a brutalidade da polícia, conhecida por sua arbitrariedade e centros de tortura, eram fatos do dia a dia que, cada vez mais, começaram a se tornar insuportáveis para os egípcios. Todos esses fatores combinados - empobrecimento dos mais pobres, enriquecimento dos mais ricos, corrupção, repressão draconiana e sucessão hereditária - fizeram dos anos 2000 uma década de intensos protestos no Egito.

Abdalla (2012) separa essas manifestações em dois ciclos, um de cunho político, entre 2004 e 2006, capitaneado pelo Kefaya, movimento cujo foco era evitar a sucessão de Mubarak por seu filho, e outro de cunho socioeconômico, iniciado em 2005 e que avançaria até 2011. Juntos, esses dois ciclos produziram 266 episódios de mobilização social em 2006, 614 em 2007, 630 em 2008 e 609 em 2009, mas eles eram "ilhas isoladas", focadas em questões específicas e sem conexão uns com os outros (ABDALLA, 2012).

As novidades do levante de 2011 foram a união de todos os movimentos e o fato de terem uma única causa em comum: a saída de Mubarak. Pressionados por 18 dias de protestos, os militares tomaram a decisão que lhes permitiria manter seu império econômico e sua influência política: afastaram Mubarak do poder, tiraram Gamal da linha de sucessão e tomaram o poder político para si. Esse status quo não se sustentaria por muito tempo, em grande parte por conta da Irmandade Muçulmana, que, após décadas de repressão, estava posicionada para desafiar os poderes estabelecidos e reivindicar o controle do Estado.

\section{CONCLUSÃO}

O artigo buscou inserir a história da Irmandade Muçulmana na história do Egito e mostrar como elas estão entrelaçadas. O movimento nasceu em oposição à dominação estrangeira do mundo muçulmano, em particular do Egito, e se desenvolveu a partir de uma visão de mundo antiocidental e anti-imperialista. Após seu 
ocaso no regime de Nasser, a Irmandade renasce no governo Sadat, na esteia do ressurgimento islâmico que varreu o Egito na década de 1970, propiciado, entre outras coisas, pelo fracasso de ideologias alternativas, como o liberalismo, o pan-arabismo e o nacionalismo. Sob Mubarak, a Irmandade se afirma como oposição viável, posição da qual desfrutaria em 2011.

Essa pesquisa ajuda a entender as origens deste movimento e pode servir de subsídio para novas investigações a respeito do islã político no Oriente Médio, seja a versão professada por grupos mais moderados, como a própria Irmandade, ou de facções jihadistas. Este estudo tem, também, potencial para auxiliar pesquisadores cujo foco seja o Egito e os acontecimentos desde 2011, como a eleição da Irmandade e sua posterior derrubada, em 2013. Além disso, a análise apresentada aqui pode embasar estudos sobre a democratização do Oriente Médio, região onde regimes autoritários continuam a ser a regra.

\section{REFERÊNCIAS}

ABDALLA, N. Social Protests in Egypt before and after the 25 January Revolution: Perspectives on the Evolution of their Forms and Features. IEMed Mediterranean Yearbook, Barcelona, p. 86-92, 2012. Disponível em: $\quad$ https://www.iemed.org/observatori-en/arees-danalisi/arxiusadjunts/anuari/med.2012/abdalla_en.pdf>. Acesso em: 13 fev. 2019.

BAKER, R. W. Sadat and After: Struggles for Egypt's Soul. Cambridge: Harvard University Press, 1990.

COOK, S. A. The Struggle for Egypt: From Nasser to Tahrir Square. New York: Oxford University Press, 2012.

ESPOSITO, J. L.; VOLL, J. O. Islam and democracy. New York: Oxford University Press, 1996.

GOLDSCHMIDT, A. A Brief History of Egypt. New York: Infobase Publishing, 2008.

IBRAHIM, S. E. The Changing Face of Egypt's Islamic Activism. In: MARR, P. (ed.). Egypt at the Crossroads: domestic stability and regional role. Washington, D.C.: National Defense University Press, 1999. p. $29-45$.

KEPEL, G. Muslim Extremism in Egypt: The Prophet and the Pharaoh. Los Angeles: University of California Press, 2003. 
KURTZER, D.; SVENSTRUP, M. Egypt's Entrenched Military. The National Interest, [online], 22 ago. 2012. Disponível em: <http://nationalinterest. org/article/egypts-entrenched-military-7343? page=show $>$. Acesso em: 13 fev. 2019.

LIMA, J. A. O Egito em uma encruzilhada: a influência dos militares na política e uma sociedade dividida. Malala, São Paulo, n. 2, p. 39-60, 2014. Disponível em: <http://www.revistas.usp.br/malala/article/view/97479>. Acesso em: 13 fev. 2019.

MITCHELL, R. P. The Society of Muslim Brothers. New York: Oxford University Press, 1993.

OSMAN, T. Egypt on the brink: From the rise of Nasser to the fall of Mubarak. New Haven and London: Yale University Press, 2011.

OTTAWAY, M.; DUNNE, M. Incumbent Regimes and the "King's Dilemma" in the Arab World: Promise and Threat of Managed Reform. Carnegie Papers, Washington, D.C., n. 88, p. $01-28,2007$. Disponível em: <https:// carnegieendowment.org/files/cp88_ruling_parties_final1.pdf>. Acesso em: 13 fev. 2019.

PARGETER, A. The Muslim Brotherhood: From Opposition to Power. Londres: Saqi Books, 2013.

PINTO ARENA, M. do C. Changing foreign policy: the Obama Administration's decision to oust Mubarak. Revista Brasileira de Política Internacional, Brasília, v. 60, n. 01, p. 01 - 17, 2017. Disponível em: < http://www.scielo. br/pdf/rbpi/v60n1/1983-3121-rbpi-0034-7329201700121.pdf $>$ Acesso em: 13 fev. 2019.

ROLL, S. Gamal Mubarak and the Discord in Egypt's Ruling Elite. Carnegie Endowment for International Peace, [online], 01 set. 2010. Disponível em: <http://carnegieendowment.org/2010/09/01/gamal-mubarak-anddiscord-in-egypt-s-ruling-elite/6bcv>. Acesso em: 13 fev. 2019.

ROY, O. Islam: The Democracy Dilemma. In: WRIGHT, $\mathrm{R}$ (ed.). The Islamists are Coming: Who they really are. Washington, D.C.: Woodrow Wilson Center Press, 2012. p. 14.

RUTHERFORD, B. K. Egypt after Mubarak: Liberalism, Islam, and Democracy in the Arab World. Oxford: Princeton University Press, 2008.

TADROS, M. The Muslim Brotherhood in Contemporary Egypt: Democracy Redefined Or Confined? Abingdon, Oxon: Routledge, 2012.

TIGNOR, R. L. Egypt: A Short History. Princeton: Princeton University Press, 2011.

WICKHAM, C. R. The Muslim Brotherhood: Evolution of an Islamist Movement. Princeton: Princeton University Press, 2013. 